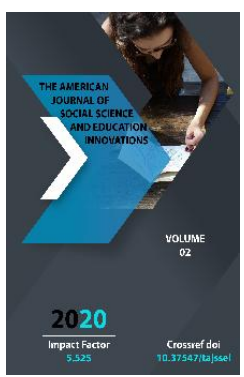

\section{Agrotourism As One Of The Prospective Directions Of The Tourist Industry}

\author{
Sayfulloev Oybek Olimovich \\ Head Of The Department Of Commercialization of Scientific And Innovative Developments Of \\ Bukhara State University, Bukhara, Uzbekistan
}

Journal Website: http://usajournalshub.c om/index,php/tajssei

Copyright: Original content from this work may be used under the terms of the creative commons attributes 4.0 licence.

\title{
ABSTRACT
}

This article examines the role of the tourism industry in the economy of its countries, as well as agrotourism, its history, stages of development, which is considered as one of the main directions of development of the tourism industry. The main features and models of agrotourism are listed. Agrotourism models and their features are shown. It describes the ongoing and planned work on the development of agrotourism in Uzbekistan. Recommendations are given on the problems facing agrotourism and their solution.

\section{KEYWORDS}

Tourism, innovation, tourist, domestic tourism, agrotourism, ecotourism, investment, tourist services.

\section{INTRODUCTION}

The tourism industry is one of the largest, most profitable and fastest growing sectors in the world economy. According to the World Tourism Organization (UNWTO), revenues from the tourism industry have only increased in the last 10 years. 1 billion a year from tourism The number of countries earning US dollars and more in 2019 doubled compared to 1998. [4] 2020 has been declared the year of rural tourism development by UNWTO. Through this, the organization expressed hope that infrastructure in rural areas would 
be improved, economic growth would be stimulated, and new jobs would be created (however, the coronavirus pandemic, which began in 2020, had temporarily dashed those hopes) [3].

\section{LITERATURE REVIEW}

In recent years, agrotourism has been recognized as one of the most promising areas of the tourism industry. The direction of agrotourism is well developed in Europe. Targeted work is being carried out in Uzbekistan to develop this sector as well. The main goal of developing this type of tourism is to strengthen the socio-economic status of villages. The development of agrotourism will create new jobs in agriculture, increase the cultural and intellectual level of the population, as well as promote the revival and development of national crafts, traditions and ceremonies. Targeted work is being carried out in Uzbekistan to develop this sector as well.

However, the work being done is not enough to reveal the potential of the agro-tourism sector. The industry is waiting for innovative steps and has a number of problems to be solved.

\section{ANALYSIS}

Agrotourism is a branch of the tourism industry that focuses on the use of natural, cultural, historical and other resources of rural areas and its specific features to create a comprehensive tourism product. This includes tourist accommodation in villages or small towns without industrial and multi-storey buildings. The main features of agrotourism are:

1. Meeting the needs of people in the process of agricultural production, in the life of the rural family, as well as in practical participation in rural society;

2. Satisfaction of people's need for rest;

3. Restoration of mental and physical condition of people;

4. Satisfaction of emotional needs based on the desire of people to interact with wildlife and nature;

Although agrotourism is recognized as a new direction in the tourism industry, it has not been a few decades since its emergence. In Europe, the state of Austria is mentioned as the homeland of agrotourism. This is due to the developed agriculture and scenic Alpine system.

Agrotourism began to develop in Europe almost 200 years ago. At that time, the 1st Association of Agrotourism was formed in France. In the 1950s, the economic, political and social potential of this direction began to emerge in France. Today in Europe, agrotourism is considered as a factor in rural development, preservation of folk traditions, development of rural infrastructure and employment of the rural population. In the developed countries of Europe, rural tourism is very popular among tourists. In terms of the level of tourist attraction, it lags behind only the coastal resorts and accounts for $20-30 \%$ of the total income of the tourism industry.

The economic basis of those engaged in agrotourism is small and medium business. Currently, there are several models of organization of agrotourism in Europe. They are:

- The British model of organization of agrotourism;

This model is primarily of interest through its unique system of tourist accommodation. 3 types of tourist accommodation are relatively popular:

1. At the farmhouse, with breakfast (farm B\&B). This method of location 
allows tourists to communicate directly with the farmer and his family.

2. Self catering unit in a separate building on a self-service basis.

3. In an insulated building (Bunk house). It usually accommodates 7 to 15 tourists in the building. This type of location is the most economical type for tourists (around 10 euros per person). This type is very popular among students. Horse riding and fishing services are recognized as the main services [6].

\section{- German model of agrotourism;}

This model is based on the joint participation of tourists and farmers in daily life and economic activities. The following 2 types of agrotourism are very popular;

- Living with a farming family and working together in the field;

- Participate in Village Day, beer festival and many other folk festivals.

\section{- French model of agrotourism;}

Cooking and winemaking are key elements in this model. At the same time, landowners offer tourists local cuisine and wine based on their own recipes.

\section{- The Italian model of agrotourism.}

This model is similar to the French, but has different aspects in terms of its characteristics. Tourists can take an active part in picking and processing fruits from vineyards and olive trees. Tourists can choose a luxury villa or a simple country house depending on their economic situation.

According to statistics, about $50 \%$ of European tourists prefer to spend their holidays in agriculture [1].
The land of Uzbekistan, as a land of ancient civilizations and cultures, has a huge tourist potential and is one of the best tourist destinations in the world. The direction of agro-tourism also has great potential as a promising direction of the tourism industry. The villages of Uzbekistan, which have their own traditions, various holidays, folklore, favorable climate and natural conditions, create the basis for the development of agrotourism. The first steps in this direction are being taken on the basis of a targeted plan.

By the Decree of the President "On measures to further develop the tourism sector in the Republic of Uzbekistan", the State Committee for Tourism Development from 2019 began to form a list of citizens' assemblies (towns, villages, auls) with tourism potential. If at least 20 family guest houses are created in the areas of citizens' gatherings and at least 5 types of services (excluding accommodation and / or catering services) are provided for tourists, they are given the status of "tourist neighborhood", "tourist village" or "tourist street". Through this status, they can enjoy a number of benefits. In particular, from 2020 they will be included in the state program "Prosperous Neighborhood" [4].

In 2019, the International Agrotourism Festival "Anor(Pomegranate)" was held in the village of Varganza, Kitob district of Kashkadarya region [9]. As part of this festival, Varganza was given the status of the 1st agro-tourism village. It is known that this village is famous for its delicious pomegranates. This is the peculiarity of the region. Within the framework of the festival, a number of interesting events related to the pomegranate fruit were held. Also, agro-tourism in Uzbekistan is relatively developed in Jizzakh and Navoi regions, on the northern slopes of the Nurata mountain range. Guest houses were established in villages such as Eski-forish, Ukhum and Hayot. 


\section{DISCUSSION}

The Kyzylkum Desert and Nurata mountain ranges, Aydar-Arnasay lakes in this region also demonstrate high potential with their unique nature, unique flora and fauna. There are many villages and mahallas in Uzbekistan with such uniqueness. Almost all regions have the necessary resources for the development of agrotourism. Tourists can be attracted from mountain and foothill landscapes to desert areas and adjacent rural areas, fields, hills, gardens, meadows. These villages can be used as additional ecological and cultural sites for visitors to the architectural and archeological monuments located near them. As a result of the interaction in agro-tourism, the rural and tourism sectors will only benefit.

Despite the targeted systematic work being done, there are several problems in Uzbekistan that hinder the development of agrotourism. The following are some suggestions and recommendations for some of these problems and their solutions:

\section{- Poor infrastructure in rural areas;}

Tourism infrastructure includes roads, transportation services, cafes and restaurants, utilities, and facilities that generally meet the basic needs of tourists. At the initial stage, agro-tourism facilities can be built in villages with relatively developed infrastructure. It is then possible to gradually select potential areas for the development of agrotourism and to form the infrastructure of these areas. It is also worth noting the activities of sanitary facilities, which seem to be a trivial problem, but cause many objections from tourists. In this regard, there has been an intensification of efforts in recent years. But enough is still a problem.

\section{- There is no economic mechanism to support investors investing in agrotourism;}

Recognizing the high socio-economic importance of the development of agrotourism in rural life, it is necessary to create a mechanism for subsidizing investors in this area. The provision of these funds on a non-refundable basis will allow the investor to recoup part of the cost and ensure the investment attractiveness of the industry. In this case, a certain amount of investor risk is borne by the state. Allocation of subsidies to investors from the state budget or special funds can take various forms:

- Interest-free loans. The principle of interest is one of the main principles of credit. In this case, the bank provides loans at normal or preferential interest rates. The interest rate is subsidized by the state;

- Subsidies in the amount of a certain part of the amount of investment;

- The agro-tourism complex is exempt from all types of utility bills for a certain period of time (usually at the initial stage);

- The agro-tourism complex is exempted from paying the tax part of salary expenses for a certain period;

- Subsidies are allocated for the costs of investors related to the organization of infrastructure;

- Marketing and advertising costs of the agro-tourism complex will be reimbursed.

If the state implements at least one of the above forms - a significant increase in investment in agrotourism. As a result of the development of the agro-tourism complex, these subsidies will be returned to the state budget in the form of taxes. 
- Unreasonably high prices for tourist services;

In Uzbekistan, agro-tourism complexes serve $80-90 \%$ of domestic tourism. We have an idea that travel is only for people with high economic potential. The high cost of tourism services also contributes to this. Investors are looking to get their investments back quickly. They choose income that comes sooner than the couch but is not sustainable.

Investors set the average payback period of investments at 3-5 years. This situation also has an impact on pricing policy. According to world practice, the payback period for 3-star hotels is 7-10 years, and for 5-star hotels - 15-20 years [8]. Entrepreneurs need to develop innovative solutions to reduce the cost of services. They should provide cost-effective tariffs, taking into account the income level of the population.

\section{- Existence of personnel problems;}

Another problem that needs to be addressed is the lack of qualified personnel to organize and conduct agro-tourism activities. The emphasis of higher education institutions on theoretical knowledge leads to insufficient formation of practical knowledge and skills in students. Also, the activity of specialized secondary educational institutions that train personnel for this area is unsatisfactory. Admittedly, today in Uzbekistan there are only a handful of companies engaged in agrotourism, which can offer jobs to highly qualified personnel. The solution to this problem can be attributed to the system of training qualified personnel for agro-tourism complexes and the increase in the number of entrepreneurs engaged in this activity. While agro-tourism complexes are an internship base for students, the trained qualified staff will serve for the development of agrotourism. There is a dual need for this activity. Another solution to the problems associated with the training system is the development of joint educational programs of higher education institutions on a collaborative basis. Agro-tourism activity is such that personnel are required to have knowledge not only in the field of tourism, but also in the field of agriculture. Therefore, it is important for the tourism industry to cooperate with educational institutions that train personnel in the field of agriculture.

\section{- The socio-economic significance of agrotourism is not fully understood.}

Despite the large-scale work being done, agrotourism is perceived not as a global sector of the economy, but as a branch of tourism. As of July 1, 2020, the rural population in Uzbekistan is $16,890.7$ thousand people. This represents 49.6 percent of the total population. Agrotourism can become an effective tool for rural development. Ensuring economic and demographic stability in rural areas is an important factor in the future development of these areas. It should be noted that in this situation, the tasks of the state will be to identify priorities for the development of agritourism, to focus on the most valuable resources of the country, to support growth points. It is also important to study the market situation in depth and identify the opportunities and risks that businesses may face.

\section{CONCLUSION}

Agrotourism brings significant potential benefits to rural areas of the country. The economic and social effects are reflected in the following forms: 
- People living here can be an important source of employment, especially in economically underdeveloped areas. Locals can work in agro-tourism complexes as waiters, retailers, gardeners, farmers, cooks and other areas related to agro-tourism activities;

- Agrotourism opens new business opportunities for the rural population;

- Agrotourism increases local budget revenues;

- Promotes the preservation of local culture and traditions as a result of agrotourism activities;

- As the agro-tourism sector is more environmentally friendly than other types of business, it has a positive impact on the implementation of measures related to environmental protection.

\section{REFERENCES}

1. Kaznacheeva S.N., Chelnokova E.A., Korovina E.A. Agritourism as one of the promising areas of the tourism industry // International Journal of Applied and Fundamental Research. - 2017. - No. 3-2. Pp. 248-252;

2. Kovalevskaya VV, Agritourism - a new type of tourism? / V. V. Kovalevskaya. Text: direct // Problems of modern economics: materials of the I International. scientific. conf. (Chelyabinsk, December 2011). Chelyabinsk: Two Komsomolets, 2011 .- P. 177.

3. https://www.eunwto.org/doi/pdf/10.18111/unwtogad.201 9.4.g51w645001604518

4. http://www.finmarket.ru/database/news/ 5153745

5. http://www.orienttracking.com/Ecology/Agroturism.htm

6. https://pandia.ru/text/77/22/50688.php
7. https://review.uz/oz/post/ozbekistonningdoimiy-aholisi-soni-malum-qilindi

8. http://rusturinvest.ru/article/investicii-vgostinichnyy-biznes-okupayutsya-dolgo1195.html

9. https://uzbektourism.uz/ru/newnews/vie w?id=769

10. https://uzbektourism.uz/cyrl/newnews/vie w?id=654\&fbclid=iwarottoiwuoo326irziu mdgigr8msgyboycehgs5dydkvk_nlrgjjr8w fcuu 